\title{
Development of Hyperprolactinemia Induced by the Addition of Bupropion to Venlafaxine XR Treatment
}

\section{Venlafaksin XR Tedavisine Bupropion Eklenmesiyle Gelişen Hiperprolaktinemi Olgusu}

Alperen KILIÇ id, Ahmet ÖZTÜRK iD, Erdem DEVECI id, İsmet KIRPINAR iD

Department of Psychiatry, Bezmialem Vakif University School of Medicine, İstanbul, Turkey

\section{ABSTRACT}

Hyperprolactinemia is characterized by abnormally increased serum prolactin levels. Menstrual irregularities and hyperprolactinemia can be caused by a variety of medical conditions as well as due to the use of some psychopharmacological drugs, namely antipsychotics; it can also develop during antidepressant treatment. Bupropion is an antidepressant functioning via the inhibition of noradrenaline and dopamine reuptake. The endocrine and sexual adverse events of this agent are rare. In the literature, only one case reporting hyperprolactinemia or galactorrhea caused by bupropion use is available. Here, we present the case of a patient diagnosed with depressive disorder and receiving venlafaxine, who developed hyperprolactinemia and oligomenorrhea after the addition of bupropion the ongoing treatment and showed serum prolactin levels decreased to normal ranges shortly after the discontinuation of bupropion.

Keywords: Bupropion, venlafaxiane, hyperprolactinemia

\section{öz}

Hiperprolaktinemi kandaki prolactin düzeyinin anormal yüksek olması durumuna denir. Menstrüasyon düzensizlikleri ve hiperprolaktinemi pek çok tıbbi duruma ve psikofarmakolojik ilaçlardan daha çok antipsikotik ajanlara bağlı olabileceği gibi antidepresanların kullanımı sonucunda da görülmektedir. Bupropion ise noradrenalin ve dopamine gerialım inhibisyonu yoluyla etki eden antidepresan bir ajandır. Bu ajanın endokrin ve cinsel yan etkileri çok nadirdir. Literatürde bupropionun hiperprolaktinemi ve yagalaktoreye neden olduğunu bildiren bir tane vaka bulunmaktadır. Biz bu yazıda depresif bozukluk tanısı ile venlafaksin XR başlanan sonrasında bupropion tedavisi eklenmesi ile hiperprolaktinemi ve oligomenore gelişen, bupropion tedavisinin kesilmesinin ardından kan prolactin seviyesi düzelen bir vaka sunduk.

Anahtar kelimeler: Bupropion, venlafaksin, hiperprolaktinemi

\section{Introduction}

Mainly associated with antipsychotic use, hyperprolactinemia and menstrual irregularities can be seen as a result of antidepressant use. Reportedly, monoaminooxidase inhibitors, tricyclic antidepressants, and selective serotonin reuptake inhibitors increase prolactin levels (1). The use of selective serotonin reuptake inhibitors, such as sertraline, fluvoxamine, fluoxetine or serotonin, and noradrenaline reuptake inhibitors, such as venlafaxine XR and duloxetine, have been shown to be associated with hyperprolactinemia and/or galactorrhea in some cases $(2,3)$. In these cases, the serotonergic mechanism is commonly attributed as the underlying cause of hyperprolactinemia and/or galactorrhea.

On the other hand, Bupropion is an antidepressant that inhibits noradrenaline and dopamine reuptake. In brief, it adjusts "decreased positive effect" symptoms in a positive way. Similar to our case, if "decreased positive effect" symptoms occur, and some residual symptoms or side effects are observed following the treatment with selective serotonin reuptake inhibitors (SSRIs) or selective noradrenaline reuptake inhibitors (SNRIs), the addition of bupropion to previous SSRI or SNRI treatment or switching to bupropion treatment have been reported to be beneficial (4).

Acting as a noncompetitive antagonist for some neuronal acetylcholine receptors (5), bupropion is known to have various biological targets; however, the mechanism of action is not completely understood. An atypical antidepressant, bupropion, has been previously reported to be neutral for prolactin mechanism and even to cause a decrease in prolactin levels since it

Cite this article as: Kılıç A, Öztürk A, Deveci E, Kırpınar i. Development of Hyperprolactinemia Induced by the Addition of Bupropion to Venlafaxine XR Treatment. Bezmialem Science 2018; 6: 150-2.

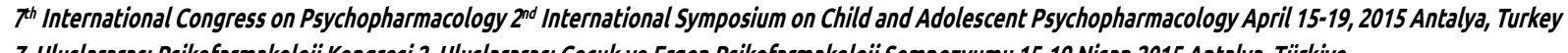
7. Uluslararası Psikofarmakoloji Kongresi 2. Uluslararası Çocuk ve Ergen Psikofarmakoloji Sempozyumu 15-19 Nisan 2015 Antalya, Türkiye 
increases dopamine reuptake (6). In literature, only one case of hyperprolactinemia and galactorrhea secondary to bupropion treatment has been reported (7). Here, we present a case in which hyperprolactinemia and oligomenorrhea developed after the initiation of bupropion treatment and serum prolactin levels decreased to normal range after the treatment was discontinued.

\section{Case Report}

A 32-year-old, married, female patient with two children was referred to our clinic. The index patient provided written informed consent for the publication of this report. On admission, she complained of headache, apathy, unwillingness to work, misery, fatigue, insomnia, and forgetfulness. Physical examination revealed no abnormalities. Her routine hemogram and biochemistry were within the normal ranges.

Her psychological examination revealed that she had the appearance of an elderly woman and appeared miserable, reckless, and oblivious. She was in a depressed mood and her affect seemed to be shallow and limited.

Venlafaxine XR treatment was initiated one year previously at our clinic since she complained of depression. She was regularly using the drug and benefitted from it in that she did not experience any menstrual irregularities (oligomenorrhea or amenorrhea) or increase in prolactin levels. She did not present with any organic disease, the chronic use of any drug, or a history of any operation. She did not smoke cigarettes, consume alcohol, or abuse any kinds of drugs/narcotics. She experienced usual menstrual cycles. She was not pregnant and was not using oral contraceptives.

At the visit, her Hamilton Rating Scale for Depression (HRSD) score was 20. According to the Structured Clinical Interview for DSM-IV Axis-1 Disorders (SCID-1), she was diagnosed as having a major depressive disorder. Venlafaxine XR was increased from $75 \mathrm{mg} /$ day to $150 \mathrm{mg} /$ day, and trazodone $(50 \mathrm{mg} /$ day) was initiated. She was followed up as an outpatient. After a month, at the follow-up, although her insomnia was resolved, she continued to complain of depression; thus, venlafaxine XR dose was increased to $225 \mathrm{mg}$ /day and trazodone $(50 \mathrm{mg} /$ day) was discontinued. After a month, she reported increased appetite after using venlafaxine XR, but she continued to complain of depression, such as the lack of attention and desire to work, insomnia, and the lack of energy. Her HRSD score was 15 . Trazadone ( $50 \mathrm{mg} /$ day) was reinitiated, and bupropion $(150 \mathrm{mg} /$ day $)$ was added to the existing treatment. Because her depressive symptoms continued at follow-up after a month, bupropion was increased to 300 $\mathrm{mg} /$ day. In the following month, she experienced menstrual irregularities (oligomenorrhea). No significant changes were reported in her hemogram, lipid profile, hepatic enzymes, urea, creatinine, or thyroid function tests. Her prolactin level was 200 , which increased to $202 \mathrm{ng} / \mathrm{ml}$ in the following week. She did not present with a history increased prolactin lev- els. To exclude the organic causes, cranial and hypophysical magnetic resonance imaging (MRI) were performed, which revealed no pathologies. Therefore, hyperprolactinemia and oligomenorrhea were considered to be drug induced. Because she had been using venlafaxine XR for a long time and because the clinical symptoms manifest a month previously, bupropion treatment was determined as the cause. Bupropion treatment was discontinued, and the control blood test a week later revealed the prolactin level decreased to $16 \mathrm{ng} /$ $\mathrm{mL}$. She experienced regular menstruation cycles. Venlafaxine XR $(225 \mathrm{mg} /$ day $)$ and trazodone $(50 \mathrm{mg} /$ day $)$ treatments were planned.

\section{Discussion}

We reported the case of bupropion-induced hyperprolactinemia and oligomenorrhea. Bupropion, an atypical antidepressant, is neutral in terms ofits effect on dopamine levels. Furthermore, bupropion may decrease prolactin levels by inhibiting dopamine reuptake. In our opinion, prolactin levels may increase during bupropion use because of the arising bupropion metabolites. The release of dopamine may be inhibited either by bupropion or its metabolites (8). Some studies have shown that bupropion acts as a noncompetitive antagonist of some nicotinic receptors $(5,9)$.

In this case, the drug interaction between venlafaxine $\mathrm{XR}$ and bupropion may be another possible triggering factor. Bupropion is a potent inhibitor of CYP2D6, which can decrease the elimination of drugs metabolized by CYP2D6 isozyme. Furthermore, according to in vitro data, venlafaxine $\mathrm{XR}$ is primarily metabolized by CYP2D6 isozyme (10). Reportedly, the effect of venlafaxine XR is dose-dependent. In our study, the patient did notexhibit any negative effects on prolactin secretion when she was on $225 \mathrm{mg} /$ day venlafaxine XR treatment. However, when bupropion was added to the ongoing treatment, she developed hyperprolactinemia and oligomenorrhea. Therefore, it is reasonable to say that the combined use of drugs may differ from their exclusive use in terms oftheir adverse events. We consider that these adverse events are due to drug-drug interactions. Thus, by inhibiting CYP2D6 isozyme, bupropion inhibits the metabolism of venlafaxine $\mathrm{XR}$ and potentiates its effect, which may explain our case.

Venlafaxine XR is an SSRI that affects serotonergic mechanism and induces hyperprolactinemia. There are two notable hypotheses regarding the increase of prolactin levels induced by serotonin. First, serotonin may increase prolactin levels by stimulating postsynaptic 5-HT receptors located in the paraventricular nucleus of the hypothalamus via serotonin agonism. Second, it may indirectly increase prolactin by inhibiting dopamine, which is known to have an inhibiting function on prolactin in the tuberoinfundibular pathway (3). Serotonin agonism has been considered to cause dopamine inhibition in the mesocortical/mesolimbic pathway using the 5-HT2C receptor. 
In our opinion, hyperprolactinemia evident in our case was caused by the potential interaction between venlafaxine XR and bupropion. In previous reports or studies, no hyperprolactinemia cases secondary to additional bupropion to any antidepressant treatments have been reported. We state that the hypothesis that bupropion metabolites act on nicotinic receptor antagonism and decrease dopamine levels, which in turn increase prolactin levels, is less likely to hold true. Only one poster presentation in the literature is available that has reported an increase in prolactin levels as a result of bupropion use (7). However, the increase in prolactin levels in this particular study was not thoroughly investigated.

\section{Conclusion}

Clinicians must be alert for hyperprolactinemia and menstrual irregularities and the possible drug-drug interactions during antidepressant treatment. The mechanism underlying the adverse events should be investigated through further research.

Informed Consent: Written informed consent was obtained from patient who participated in this case.

Peer-review: Externally peer-reviewed.

Author Contributions: Concept - A.K.; Design - A.K., A.Ö.; Supervision - E.D., İ.K.; Data Collection and/or Processing - A.K.; Analysis and/or Interpretation - A.Ö., E.D., İ.K., A.K.; Literature Search - A.K., A.Ö.; Writing Manuscript - A.K., A.Ö.; Critical Review - A.Ö., E.D., İ.K.; Other - A.Ö., İ.K., E.D.

Conflict of Interest: No conflict of interest was declared by the authors.

Financial Disclosure: The authors declared that this study has received no financial support.

Hasta Onamı: Yazılı hasta onamı bu olguya katılan hastadan alınmıştır.

Hakem Değerlendirmesi: Dış bağımsız.
Yazar Katkıları: Fikir - A.K.; Tasarım - A.K., A.Ö.; Denetleme E.D., İ.K.; Veri Toplanması ve/veya İşlemesi - A.K.; Analiz ve/veya Yorum - A.Ö., E.D., İ.K., A.K.; Literatür Taraması - A.K., A.Ö.; Yazıyı Yazan - A.K., A.Ö.; Eleştirel İnceleme - A.Ö., E.D., İ.K.; Diğer - A.Ö., İ.K., E.D.

Çıkar Çatışması: Yazarlar çıkar çatışması bildirmemişlerdir.

Finansal Destek: Yazarlar bu çalışma için finansal destek almadıklarını beyan etmişlerdir.

\section{References}

1. Wieck A, Haddad PM. Antipsychotic-induced hyperprolactinaemia in women: pathophysiology, severity and consequences. Br J Psychiatry 2003; 182: 199-204. [CrossRef]

2. Bronzo MR, Stahl SM. Galactorrhea induced by sertraline (letter). Am J Psychiatry 1993; 150: 1269-70. [CrossRef]

3. Yang MS, Cheng WJ, Huang MC. Dose-related hyperprolactinemia induced by venlafaxine. Prog Neuropsychopharmacol Biol Psychiatry 2009; 33: 733-4. [CrossRef]

4. Stahl SM. Noradrenaline and dophamine reuptake inhibitors, Stahl's Essential Psychopharmacology: Neuroscientific Basis and Practical Applications. 4nd ed. Cambridge University Press; 2013. p.309-12.

5. Arias HR, Santamaria A, Ali SF. Pharmacological and neurotoxicological actions mediated by bupropion and diethylpropion. Int Rev Neurobiol 2009; 88: 223-55. [CrossRef]

6. Meltzer HY, Fang VS, Tricou BJ, Robertson A. Effect of antidepressants on neuroendocrine axis in humans. Adv Biochem Psychopharmacol 1982; 32: 303-16.

7. Bilgin A, Cam B. Bupropion associated with galactorrhea: a case report. Bull Clin Psychopharmacol 2012; 22: 153.

8. Damaj MI, Carroll FI, Eaton JB, Navarro HA, Blough BE, Mirza S, et al. Enantioselective effects of hydroxy metabolites of bupropion on behavior and on function of monoamine transporters and nicotinic receptors. Mol Pharmacol 2004; 66: 67582. [CrossRef]

9. Fryer JD, Lukas RJ. Noncompetitive functional inhibition at diverse, human nicotinic acetylcholine receptor subtypes by bupropion, phencyclidine, and ibogaine. J Pharmacol Exp Ther 1999; 288: 88-92.

10. Otton SV, Ball SE, Cheung SW, Inaba T, Rudolph RL, Sellers EM. Venlafaxine oxidation in vitro is catalysed by CYP2D6. Br J Clin Pharmacol 1996; 41: 149-56.[CrossRef] 